\title{
Actinomycosis presenting as an isolated pleural effusion in a patient with an HIV infection: a case report and literature review
}

Jung Wan Park², Yon Hee Kim³ ${ }^{3}$ Eunjung Lee ${ }^{\text {* }}$, Se Yoon Park and Tae Hyong Kim

\begin{abstract}
Background: Thoracic actinomycosis is an uncommon, chronic, and progressive infection, especially in patients with HIV. We report a case of thoracic actinomycosis presenting as an isolated pleural effusion in a patient with an HIV infection.

Case presentation: A 68-year-old patient with progressive dyspnea and fever was admitted. On the right side, an ipsilateral massive pleural effusion was confirmed on the chest radiograph, and an HIV infection was newly diagnosed. A pleural biopsy was performed for the further differential diagnosis of potential opportunistic infections and malignancies. The pathology findings were consistent with actinomycosis.

Conclusions: Active diagnostic approaches such as a pleural biopsy should be considered for indeterminate pleural effusions in immunocompromised patients.
\end{abstract}

Keywords: Human immunodeficiency virus, Actinomycosis, Pleural effusion

\section{Background}

Actinomycosis is a relatively rare, chronic, and progressive infection caused by Actinomyces species, which are part of the human mucosal flora. Thoracic involvement with Actinomyces constitutes approximately $15 \%$ of the patients diagnosed with actinomycosis and an isolated pleural effusion is a rare clinical presentation of thoracic actinomycosis $[1,2]$. We report a rare case of thoracic actinomycosis presenting as an isolated pleural effusion in a newly diagnosed HIV-infected patient along with a literature review.

\footnotetext{
${ }^{*}$ Correspondence: shegets@schmc.ac.kr

1 Department of Internal Medicine, Soonchunhyang University Seoul

Hospital, Soonchunhyang University College of Medicine, Seoul, Republic of Korea

Full list of author information is available at the end of the article
}

\section{Case presentation}

A 68-year-old man with a history of smoking and without comorbid conditions was admitted to the emergency department on February 28, 2021, with a 15-day history of progressive and worsening dyspnea. He also reported chills and a productive cough. His medical history included herpes zoster and an inguinal hernia. $\mathrm{He}$ had no history of thoracic traumatic injury or any other surgeries.

The patient's body temperature at the time of admission was $39.0^{\circ} \mathrm{C}$, with a heart rate of 141 beats $/ \mathrm{min}$ and blood pressure of $174 / 107 \mathrm{mmHg}$. The patient's oxygen saturation was $77 \%$ while breathing ambient air. The physical examination was remarkable for decreased lung sounds and wheezy breathing sounds with rales over the entire right lung. Laboratory tests revealed a white blood cell count of $20.000 / \mathrm{mm}^{3}$, a hemoglobin level of $11.8 \mathrm{~g} /$ $\mathrm{dL}$, a platelet count of $455 \times 10^{3} / \mu \mathrm{L}$, a C-reactive protein level of $34.6 \mathrm{mg} / \mathrm{dL}$, and a procalcitonin level of $59.42 \mathrm{ng} /$ $\mathrm{mL}$. The HIV antigen/antibody combination test revealed original author(s) and the source, provide a link to the Creative Commons licence, and indicate if changes were made. The images or other third party material in this article are included in the article's Creative Commons licence, unless indicated otherwise in a credit line to the material. If material is not included in the article's Creative Commons licence and your intended use is not permitted by statutory regulation or exceeds the permitted use, you will need to obtain permission directly from the copyright holder. To view a copy of this licence, visit http://creativecommons.org/licenses/by/4.0/. The Creative Commons Public Domain Dedication waiver (http://creativeco mmons.org/publicdomain/zero/1.0/) applies to the data made available in this article, unless otherwise stated in a credit line to the data. 
a positive result and the real-time polymerase chain reaction (PCR) test for HIV was $1.11 \times 10^{5}$ copies $/ \mathrm{mL}$. The CD4 + T-lymphocyte cell count was 308 cells/ $\mu \mathrm{L}(15 \%)$.

Chest radiography showed a totally whited-out right lung and chest computed tomography $(\mathrm{CT})$ revealed a large amount of right pleural effusion, diffuse pleural enhancement, and multifocal low dense lesions in the right lobe (Fig. 1A: chest radiograph, B: chest CT). Percutaneous catheter drainage of pleural fluid and pleural fluid analysis were done on the third day after admission to relieve dyspnea and make a differential diagnosis. Pleural fluid analysis revealed an exudate of white blood cells $(3860 / \mu \mathrm{L})$ and an adenosine deaminase (ADA) level of $179 \mathrm{IU} / \mathrm{L}$. The white blood cell differential count was not available due to multiple lysed cells. Cytologic examination of the pleural effusion and sputum revealed several acute inflammatory cells and necrotic cellular debris without microorganisms. No malignant cells were found in the pleural fluid. Based on the high level of pleural ADA and the newly diagnosed HIV infection, a presumptive diagnosis of tuberculosis (TB) pleurisy was made. Anti-tuberculosis treatment was initiated, although the acid-fast bacilli (AFB) stain and culture results, as well as tuberculosis real-time PCR analysis of the pleural fluid, were negative. The TB-specific antigen interferon (INF)gamma was negative. A pleural biopsy was performed on day 6 after admission, which revealed two tiny fragments of pleura showing abundant acute and chronic inflammatory cell infiltrates with ovoid basophilic radiating filaments under light microscopy, consistent with actinomycosis (Fig. 2). Anti-tuberculosis medications were stopped. Intravenous ampicillin $(200 \mathrm{mg} / \mathrm{kg} / \mathrm{day})$ was administered and anti-retroviral therapy (tenofovir alafenamide fumarate/emtricitabine/bictegravir) was initiated. After 4 weeks of parenteral ampicillin, the patient was switched to oral amoxicillin for 11 months. Chest radiography performed during a follow-up 15 months later revealed a small amount of loculation in the right hemithorax. The patient came to the hospital on September 28,2021 , and did not complain of any special symptoms. There were no abnormal findings in most of the examination results including the chest $\mathrm{X}$-ray.

\section{Discussion and conclusion}

A unique case of isolated pleural actinomycosis was confirmed in an HIV patient without a history of thoracic trauma or surgery. The clinical presentation of the patient in this case was fever, progressive dyspnea, and unilateral pleural thickening with massive effusion. In this case, only an aggressive pleural biopsy provided a timely diagnosis and guided the actinomycosis treatment.

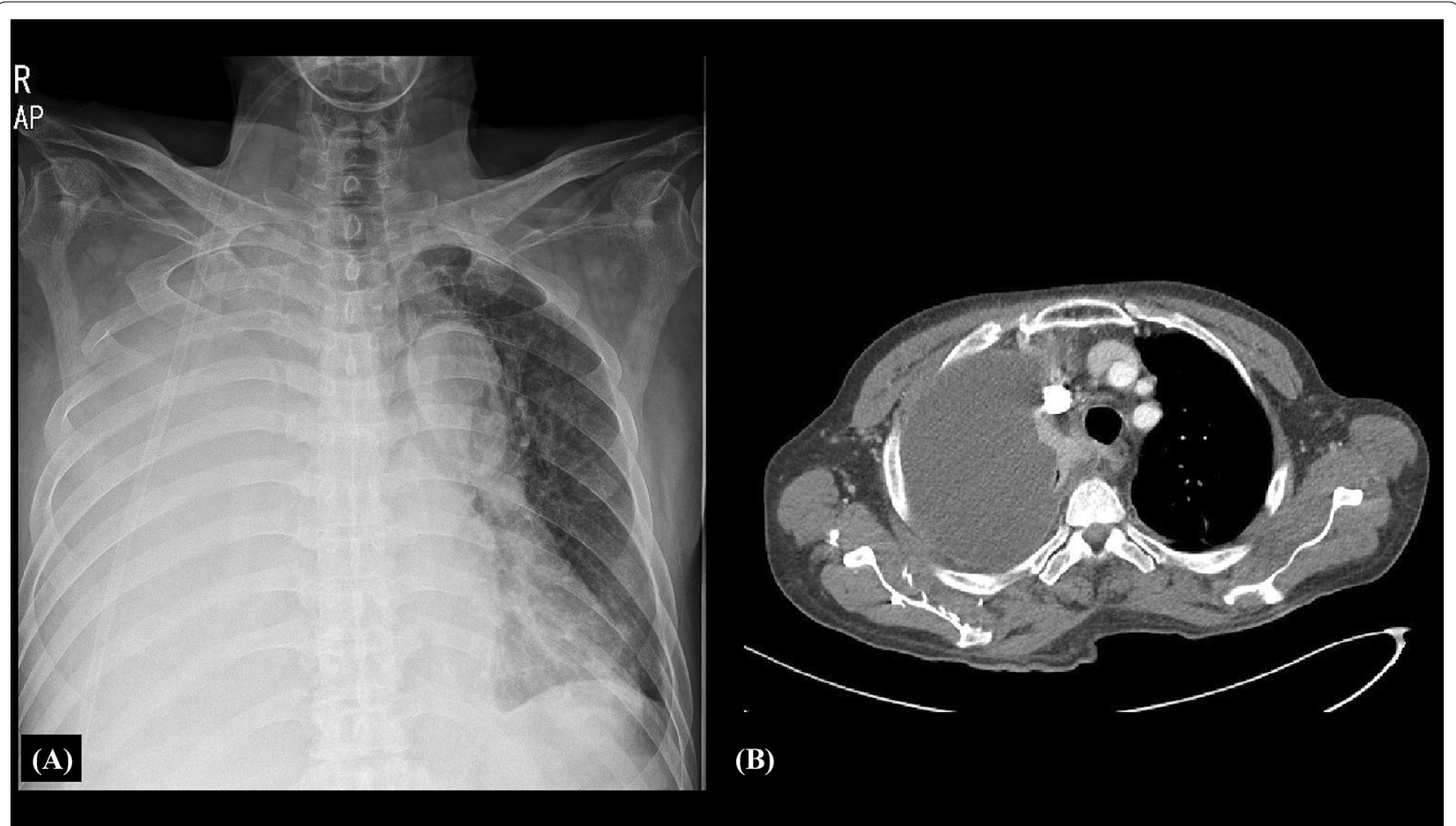

Fig. 1 A, B Chest radiograph and chest computed tomography. The chest radiography showed a totally whited-out right lung and chest computed tomography revealed a large amount of right pleural effusion and diffuse pleural enhancement 


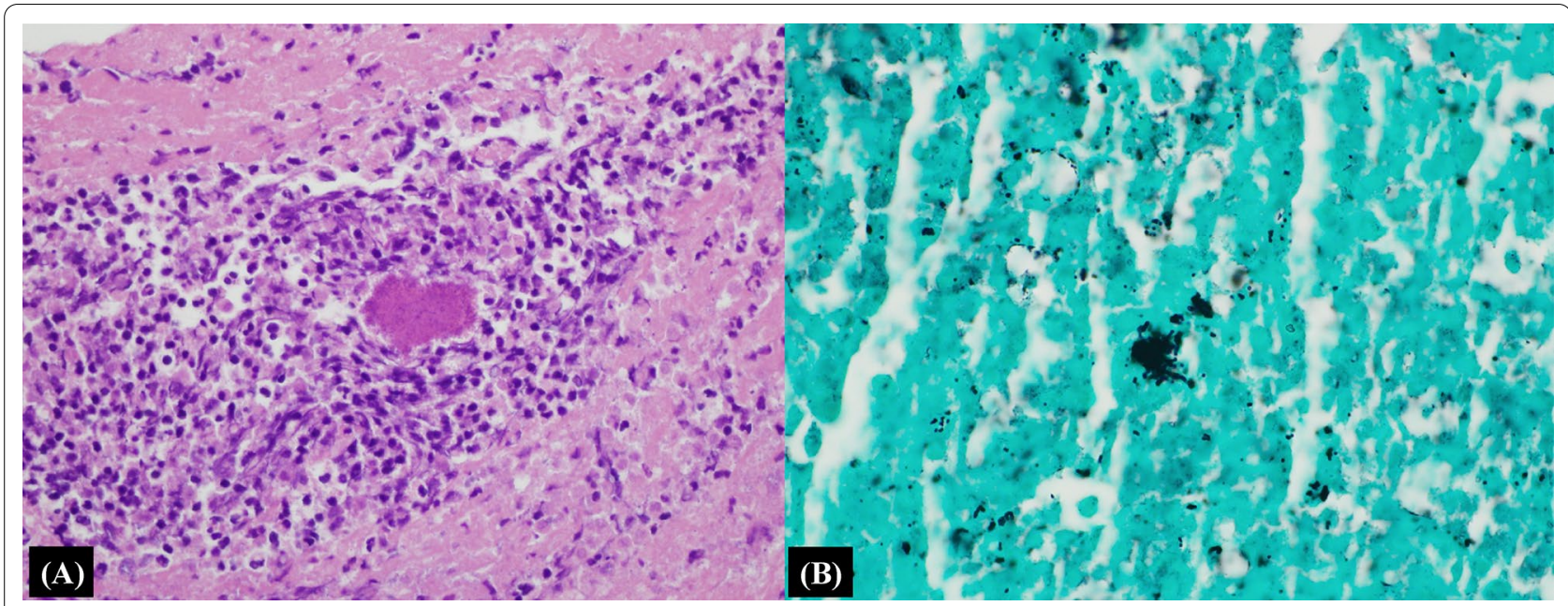

Fig. 2 A Histologic examination: hematoxylin and eosin $(H \& E)$ staining $(\times 400)$. A bacterial colony (sulfur granule) is found at the center of mixed inflammatory cells. B Grocott methenamine silver stain (GMS) stain ( $\times 1000)$. The GMS stain demonstrates filamentous bacteria

The main symptoms of thoracic actinomycosis were cough expectoration, blood-stained sputum, hemoptysis, fever, and chest pain [1,3]. Radiographically, thoracic actinomycosis may involve either lung and show multiple cavitary lesions. A mass lesion or pneumonia with or without pleural involvement is usual and pleural thickening, effusion, or empyema is found in more than $50 \%$ of the cases [4]. Otherwise, an isolated pleural effusion is an extremely rare clinical presentation of thoracic actinomycosis. In addition, an organism is not often isolated from a pleural effusion. The previously reported cases showed the diverse clinical features of an isolated pleural effusion in thoracic actinomycosis, but the cases were generally associated with structural injury or thoracic surgery [5-8]. However, the patient in our case had no history of thoracic trauma or surgery and had a newly diagnosed HIV infection.

Only four case reports in patients with HIV have been published [9-12]. We reviewed a total of five case reports involving thoracic actinomycosis in patients with an HIV infection, including our patient (Table 1). It was difficult to determine the patients' immunity levels because of inappropriate $\mathrm{CD} 4$ count reporting. However, three patients including our patient, received anti-retroviral therapy (ART). Most patients were first suspected to have other diseases (e.g., pulmonary tuberculosis, lung mass, Pneumocystis jiroveci pneumonia) and were treated accordingly. Nevertheless, symptom improvement was slow, and thoracic actinomycosis was confirmed via sulfur granules or Actinomyces species detected in trans-bronchial lung biopsy
(TBLB) or bronchoalveolar lavage (BAL) samples. All patients were treated with intravenous penicillin $\mathrm{G}$ or peroral amoxicillin, and the duration of treatment varied from 3 weeks to 12 months. The patient in our case was also successfully treated for 12 months. All but one patient improved. The single patient death was attributed not to thoracic actinomycosis but superimposed cryptococcal meningitis.

Cases of actinomycosis have been reported in the setting of immunocompromised conditions including HIV infections [13]. Actinomycosis combined with immunosuppression is associated with higher mortality than immunosuppression alone. A multicenter retrospective study conducted in Paris from 1997 to 2009 showed death in $21 \%$ of all cases of invasive actinomycosis and was associated with immunocompromised status $(p=0.027)[14]$. Thus, the recognition of actinomycosis is a more important issue in immunocompromised patients such as those with HIV infections. However, actinomycosis is uncommon, with limited clinical experience, and laboratory investigations are challenging [15]. Therefore, a broad differential diagnosis with uncommon manifestations should be considered and active diagnostic approaches are needed.

In conclusion, isolated pleural effusion is a rare clinical presentation of thoracic actinomycosis. However, actinomycosis can be fatal in immunocompromised patients such as HIV-infected individuals. Active diagnostic approaches such as a pleural biopsy should be considered in immunocompromised patients with an indeterminate pleural effusion. 


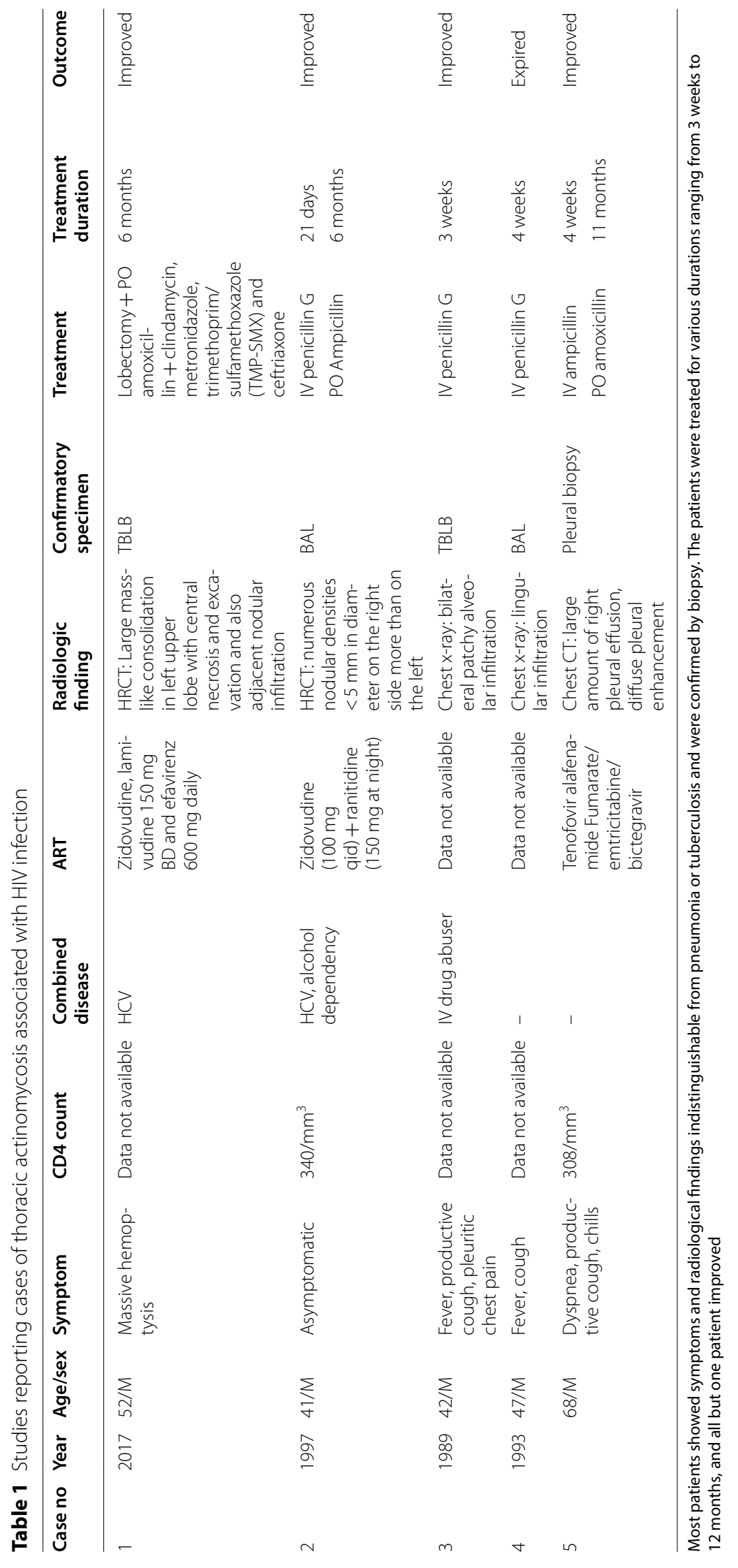




\section{Abbreviations}

HIV: Human immunodeficiency virus; TB: Tuberculosis; ART: Antiretroviral therapy; TBLB: Transbronchial lung biopsy; BAL: Bronchoalveolar lavage; ADA: Adenosine deaminase; PCR: Polymerase chain reaction; CT: Computed tomography; INF: Interferon.

\section{Acknowledgements}

We express our gratitude to all the medical staff involved in the management of the patient in this case.

\section{Authors' contributions}

JWP is the first author who contributed to the writing of the paper and performed the analysis. EJ is the author for correspondence and contributed to the study design, analysis, data collection, and writing of the paper SYP contributed to the design and analysis as well as the article review. YHK provided technical assistance and performed data collection. THK contributed to the data review and manuscript revision. All authors read and approved the final manuscript.

\section{Funding}

This research was supported by the Soonchunhyang University Research Fund.

\section{Availability of data and materials}

The data that support the findings of this study are openly available.

\section{Declarations}

Ethics approval and consent to participate

Not applicable.

\section{Consent for publication}

Not applicable.

\section{Competing interests}

The authors declare that they have no conflicts of interest.

\section{Author details}

1 Department of Internal Medicine, Soonchunhyang University Seoul Hospital, Soonchunhyang University College of Medicine, Seoul, Republic of Korea. ${ }^{2}$ Department of Internal Medicine, Soonchunhyang University Cheonan Hospital, Soonchunhyang University College of Medicine, Cheonan, Republic of Korea. ${ }^{3}$ Department of Pathology, Soonchunhyang University Seoul Hospital, Soonchunhyang University College of Medicine, Seoul, Republic of Korea.

Received: 7 August 2021 Accepted: 2 November 2021

Published online: 17 November 2021

\section{References}

1. Mabeza GF, Macfarlane J. Pulmonary actinomycosis. Eur Respir J. 2003;21(3):545-51.

2. Bennett JE, Dolin R, Blasesr MJ. Mandell, Douglas, and Bennett's principles and practice of infectious diseases, vol. II. 9th ed. Philadelphia, PA: Elsevier/Saunders; 2020. p. 3071-81.

3. Zhang $M$, Zhang $X Y, C$ Chen $Y B$. Primary pulmonary actinomycosis: a retrospective analysis of 145 cases in mainland China. Int J Tuberc Lung Dis. 2017;21(7):825-31.

4. Cheon JE, Im JG, Kim MY, Lee JS, Choi GM, Yeon KM. Thoracic actinomycosis: CT findings. Radiology. 1998;209(1):229-33.

5. Touboul JL, Chaussade F, Desvignes B, Mangeney T, Bidault C. Isolated pleural actinomycosis. Apropos of 2 cases. Rev Pneumol Clin. 1990;46(2):69-72.

6. Sarker C, Rahman S, Siddiqui N, Huq M, Musa A, Talukder S, Alam K, Debnath C, Kabir A, Saleh FJ. Thoracic actinomycosis. Mymensingh Med J. 2004;13(1):88-90.

7. Coodley EL, Yoshinaka R. Pleural effusion as the major manifestation of actinomycosis. Chest. 1994;106(5):1615-7.

8. Moskowitz SM, Shailam R, Mark EJ. Case 25-2015: an 8-year-old girl with a chest-wall mass and a pleural effusion. NEJM. 2015;373(7):657-67.

9. Tabarsi P, Yousefi S, Jabbehdari S, Marjani M, Baghaei P. Pulmonary actinomycosis in a patient with AIDS/HCV. J Clin Diagn Res. 2017;11(6):Od15-7.

10. Ossorio MA, Fields CL, Byrd RP Jr, Roy TM. Thoracic actinomycosis and human immunodeficiency virus infection. South Med J. 1997;90(11):1136-8.

11. Klapholz A, Talavera W, Rorat E, Salsitz E, Widrow C. Pulmonary actinomycosis in a patient with HIV infection. Mt Sinai J Med. 1989;56(4):300-3.

12. Cendan I, Klapholz A, Talavera W. Pulmonary actinomycosis. A cause of endobronchial disease in a patient with AIDS. Chest. 1993;103(6):1886-7.

13. Murchan EM, Redelman-Sidi G, Patel M, DiMaio C, Seo SK. Esophageal actinomycosis in a fifty-three-year-old man with HIV: case report and review of the literature. AIDS Patient Care STDS. 2010;24(2):73-8.

14. Pierre I, Zarrouk V, Noussair L, Molina J-M, Fantin B. Invasive actinomycosis: surrogate marker of a poor prognosis in immunocompromised patients. Int J Inf Dis. 2014;29:74-9.

15. Bonnefond S, Catroux M, Melenotte C, Karkowski L, Rolland L, Trouillier S, Raffray L. Clinical features of actinomycosis: A retrospective, multicenter study of 28 cases of miscellaneous presentations. Medicine. 2016;95(24): e3923.

\section{Publisher's Note}

Springer Nature remains neutral with regard to jurisdictional claims in published maps and institutional affiliations.
Ready to submit your research? Choose BMC and benefit from:

- fast, convenient online submission

- thorough peer review by experienced researchers in your field

- rapid publication on acceptance

- support for research data, including large and complex data types

- gold Open Access which fosters wider collaboration and increased citations

- maximum visibility for your research: over $100 \mathrm{M}$ website views per year

At BMC, research is always in progress.

Learn more biomedcentral.com/submissions 